\title{
The Influence of Perception About Working World Information Based on Student Work Readiness at SMK Negeri 1 Sumedang
}

\author{
(Study Case: in SMK Negeri 1 Sumedang)
}

\author{
Muhamad Ridho Bagja Nugraha, Lilis Widaningsih*, Trias Megayanti \\ Department of Architectural Engineering Education, Faculty of Technology and Vocational Education \\ Universitas Pendidikan Indonesia \\ Bandung, Indonesia \\ *liswida@upi.edu, ridhonugraha30@student.upi.edu
}

\begin{abstract}
The unemployment rate for vocational high school graduates is very high. Initial observations show that not all of the Vocational high school graduates have the readiness and skills to enter the working world. It is also shown that Vocational high school students still have difficulty in determining the choice to pursue a career in the future. This study aims to determine the influence of students' perceptions of working world information on student work-readiness. A correlational quantitative approach was conducted in this study, utilizing questionnaires and documentation as data collection tools. The population in this study were $x$ grade students of 1st public vocational high school of Sumedang in the 2019/2020 academic year. Involving 63 representative students from all study programs at 1st Public Vocational High School of Sumedang (SMKN 1 Sumedang), the sampling technique used was convenience sampling. The data analysis used in this study was a simple linear regression analysis. The result shows both students' perception of working world information and students' work-readiness is in the excellent category. The Perception of the working-world has a high impact on work-readiness among the students. Thus, vocational high school students should enrich themselves with various information about the working-world from trusted sources in order to conceive better work-readiness after graduation.
\end{abstract}

Keywords-perception, working world information, student work readiness

\section{INTRODUCTION}

Increasing the quality of SMK in producing skilled personnel is considered important, because not all SMK graduates have the competence and world of work servers in accordance with their field of expertise. The gap that occurs between the quality of SMK graduates with the competency needs of skilled workers in the world of work is increasing every day, one of the factors that influence this is the readiness of the SMK students themselves. Information on the world of work that can affect students 'work readiness through students' own perceptions, where students see, hear, and feel a picture of the world of work will increase work readiness. Students need a lot of information about the world of work to make it easier for them to see the conditions and requirements to apply for the jobs they want. Lack of information on the world of work will have an impact on the condition of students who are empty of how the conditions and requirements in all jobs are. In learning, students of SMKN 1 Sumedang are given material both theory and practice that are applicable since the beginning of the teaching and learning process. So that it is expected that students can have competencies in accordance with their field of expertise. In fact, graduates of SMKN 1 Sumedang have not yet perfected their students to enter the world of work even though students of SMKN 1 Sumedang have been equipped with competences, knowledge and real experience of the world of work. This is evidenced by the data of graduates in 2019 which it is known that students who work as much as $37.5 \%$, continue to college as much as $14 \%$, entrepreneurship $17.3 \%$ have not worked as much as $8.2 \%$ and the other $23 \%$ are not detected. According to these data, it can be believed that SMKN 1 Sumedang has not been able to market all of its graduates to work. The solution between information on the world of work provided by schools that is already very good with work readiness that is classified as low.

\section{RESEARCH METHODS}

This research uses correlational research, which is to determine the extent to which a factor is related to other factors based on the correlation coefficient. The approach used is a quantitative approach, where this approach is a process of finding new knowledge using data in the form of numbers as a tool to find the information you want to know in measuring the effect of perceptions about information on the world of work on student work readiness.

The research population consisted of 530 people, namely all students of class XII for the 2019/2020 school year who were spread into 10 departments. The sample taken was $10 \%$ 
of the number of students for each department, so the total sample was 63 people. Variable X perceptions of information on the world of work uses 5 indicators, namely: (1) information material must be clear, accurate and precise, (2) information material must be relevant for a certain level of education, (3) information material must be presented attractively, (4) information material must be free from subjective factors, (5) information material must have benefits for secondary education level students. Whereas for the $\mathrm{Y}$ variable student work readiness uses 8 indicators, namely: (1) Having logical and objective considerations, (2) Having the ability and willingness to cooperate with others, (3) Able to control yourself / emotions, (4) Have an attitude critical, (5) Having the courage to accept individual responsibilities, (6) Having the ability to adapt to the environment / technological developments, (7) Having the ambition to advance and (8) trying to keep up with developments and areas of expertise. After obtaining responses from related respondents, the data will be tested using the correlation coefficient test, regression coefficient test and determination coefficient test.

\section{RESULTS AND DISCUSSION}

This study was intended to measure the variable perceptions of information on the world of work on students' job readiness. Variable $\mathrm{X}$ is the perception of information about the world of work which consists of 5 indicators, including information must be clear, accurate, and precise, then information must be relevant, information must be presented attractively, information must be free from subjective factors, and information must be useful with 15 questions. (fifteen) questions. The results of the answers of 63 respondents are as follows:

TABLE I. X VARIABLE INDICATORS

\begin{tabular}{|l|c|c|c|}
\hline \multicolumn{1}{|c|}{ Indicator } & Average & Percentage & Category \\
\hline $\begin{array}{l}\text { Information must be clear, } \\
\text { accurate, and precise }\end{array}$ & 3.32 & $83.06 \%$ & $\begin{array}{c}\text { Very } \\
\text { Good }\end{array}$ \\
\hline Information must be relevant & 2.88 & $71.92 \%$ & Good \\
\hline $\begin{array}{l}\text { Information must be presented } \\
\text { attractively }\end{array}$ & 3.22 & $80.42 \%$ & $\begin{array}{c}\text { Very } \\
\text { Good }\end{array}$ \\
\hline $\begin{array}{l}\text { Information should be free of } \\
\text { subjectivity }\end{array}$ & 3.17 & $79.37 \%$ & $\begin{array}{c}\text { Very } \\
\text { Good }\end{array}$ \\
\hline information is helpful to be & 3.48 & $86.90 \%$ & $\begin{array}{c}\text { Very } \\
\text { Good }\end{array}$ \\
\hline Total & $\mathbf{3 . 2 1}$ & $\mathbf{8 0 . 3 4 \%}$ & $\begin{array}{c}\text { Very } \\
\text { Good }\end{array}$ \\
\hline
\end{tabular}

From the results of these answers show that the average achievement of the perception variable about information on the world of work is 3.21 with a percentage of $80.34 \%$ belonging to the "very good" category. Each indicator that explains perceptions about information on the world of work has a different average value which will be described as follows:

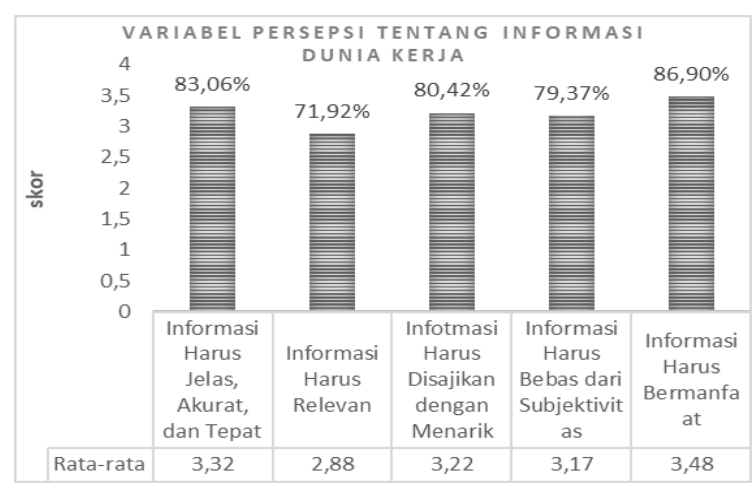

Fig. 1. X Variable indicators

The average value of the responses of 63 respondents from each study program to the perception variable about information on the world of work, more details can be seen through the following diagram:

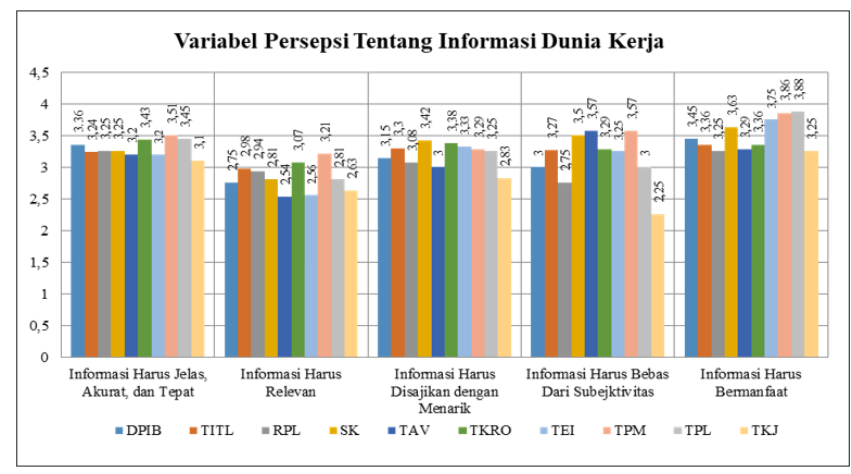

Fig. 2. X Variable on SMKN 1 Sumedang Department

Diagram above explains the difference in the level of achievement of the scores for each study program of SMKN 1 Sumedang on each indicator in the perception variable about information on the world of work.

The highest average achievement in the perception variable regarding information on the world of work was obtained by the TPM study program, followed by the TKRO study program, SK, TPL, TITL, TEI, DPIB, TAV, RPL, and finally the TKJ study program. This shows the high perception of information on the world of work experienced by the TPM study program as the biggest contributor to the perception variable about information on the world of work. The highest range of values is obtained by the fourth indicator with a range of 1.32 and the lowest range is obtained by the first indicator with a range of 0.41 .

Variable $\mathrm{Y}$ is student work readiness consisting of 8 (eight) indicators, including logical and objective readiness, critical attitude, emotional control, adapting to the environment, being responsible, having ambition to advance, following areas of expertise, and being able to work together with others 21 (twenty-one) questions. The results of the responses of 63 respondents are as follows: 
TABLE II. Y VARIABLE INDICATORS

\begin{tabular}{|l|c|c|c|}
\hline \multicolumn{1}{|c|}{ Indicators } & Average & Percentage & Category \\
\hline $\begin{array}{l}\text { Logical and Objective } \\
\text { Readiness }\end{array}$ & 3.21 & $80.16 \%$ & Very High \\
\hline Critical Attitude & 3.26 & $81.43 \%$ & Very High \\
\hline Emotional Control & 3.29 & $82.34 \%$ & Very High \\
\hline $\begin{array}{l}\text { Adaptable to the } \\
\text { Environment }\end{array}$ & 3.39 & $84.72 \%$ & Very High \\
\hline Responsible & 3.40 & $85.08 \%$ & Very High \\
\hline $\begin{array}{l}\text { Have the Ambition to } \\
\text { Advance }\end{array}$ & 3.48 & $87.04 \%$ & Very High \\
\hline $\begin{array}{l}\text { Follow the field of } \\
\text { expertise }\end{array}$ & 3.09 & $77.28 \%$ & Very High \\
\hline Able to Work Together & 3.60 & $89.88 \%$ & Very High \\
\hline Total & $\mathbf{3 . 3 4}$ & $\mathbf{8 3 . 4 9 \%}$ & $\begin{array}{l}\text { Very } \\
\text { High The }\end{array}$ \\
\hline
\end{tabular}

Results of these answers indicate that the average achievement of the student work readiness variable is 3.34 with a percentage of $83.49 \%$ which is included in the category. "very high". Each indicator that explains student work readiness has a different average value which will be described as follows:

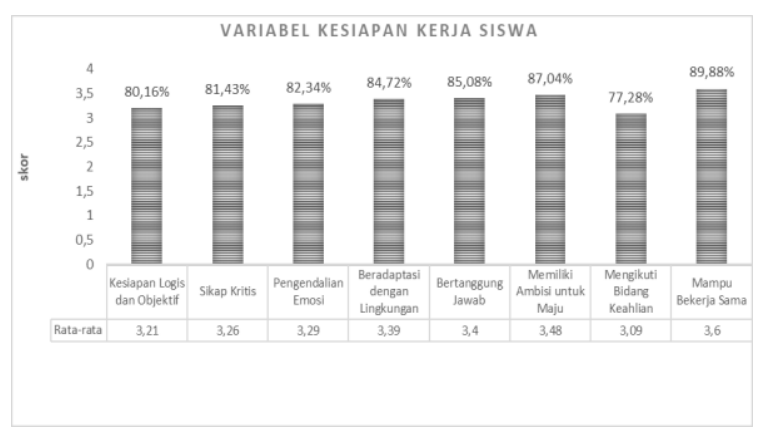

Fig. 3. Y variable indicators

Average responses of 63 respondents from each study program of SMKN 1 Sumedang regarding student work readiness variables, more details can be seen in the following diagram:

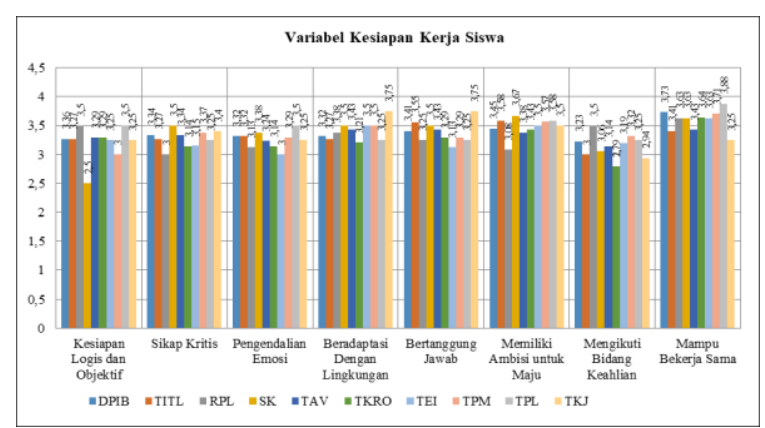

Fig. 4. Y indicator on SMKN 1 Sumedang department.

Correlational coefficient analysis used in this test uses the formula Pearson product moment. The purpose of this test is to find out whether there is a correlation between two variables with the same type of data and a normal distribution. So this analysis aims to determine the correlation between perceptual variables about the world of work information (X) to the student work readiness variable (Y). The results of the simple correlation coefficient test will be explained in the following table:

TABLE III. CORELATION COEFICIENT

\begin{tabular}{|l|c|c|c|}
\hline \multicolumn{1}{|c|}{ Variable } & $\begin{array}{c}\text { Value of } \\
\text { Pearson } \\
\text { Correlation }\end{array}$ & $\begin{array}{c}\text { Interval } \\
\text { Coefficient }\end{array}$ & Information \\
\hline $\begin{array}{l}\text { Perception of } \\
\text { information } \\
\text { about the } \\
\text { world of work } \\
\text { on student } \\
\text { work readiness }\end{array}$ & 0.617 & $0.600-0.799$ & $\begin{array}{c}\text { Strong } \\
\text { relationship }\end{array}$ \\
\hline
\end{tabular}

Based on the table above shows the correlation coefficient value of 0.617 which is in the interval coefficient of $0.600<r_{x y}$ $<0.799$. This concludes that the relationship between perceptual variables about information on the world of work on students' job readiness is classified as a scale strong relationship.

Next will be explained about the simple linear regression test through the following table:

TABLE IV. REGRESSION COEFICIENT.

\begin{tabular}{|l|c|c|c|c|}
\hline Variable & $\begin{array}{c}\text { Regression } \\
\text { Coefficient } \\
\text { (b) }\end{array}$ & $\mathbf{t}_{\text {count }}$ & Significance & Information \\
\hline $\begin{array}{l}\text { Perception } \\
\text { about } \\
\text { information } \\
\text { about the } \\
\text { world of } \\
\text { work on } \\
\text { student } \\
\text { work } \\
\text { readiness }\end{array}$ & 0.773 & 6.123 & 0.000 & Positive \\
\hline \multicolumn{4}{|l}{ influence Constant (a)=32.684 The } \\
\hline
\end{tabular}

Table above shows for perception Regarding information on the world of work on students' job readiness, it is obtained a constant (a) with a value of 32.684, and a regression coefficient (b) with a value of 0.773 . So that the regression equation is as follows:

$\widehat{\mathrm{Y}}=a+b X$

$\widehat{\mathrm{Y}}=32,684+0,773 X$

The regression coefficient $\mathrm{X}$ is equal to 0.773 , which states that every addition of 1 (one) value of perceptions about information on the world of work, then the value of work readiness increases by 0.773 or an increase of $r$. The regression coefficient is positive, so it can be concluded that the direction of the influence of variable $\mathrm{X}$ on variable $\mathrm{Y}$ has a positive effect. 
Calculation of the t-test to compare the acquisition of $t_{\text {arithmetic }}$ with $t_{\text {table }}$ with the calculated results of data processing as follows:

TABLE V. HYPOTESHESIS TEST

\begin{tabular}{|l|c|c|c|}
\hline \multicolumn{1}{|c|}{ Variable } & $\mathbf{t}$ & $\mathbf{t}_{\text {table }}$ & Description \\
\hline $\begin{array}{l}\text { Perceptions of } \\
\text { job market } \\
\text { information on } \\
\text { job readiness of } \\
\text { students }\end{array}$ & 6.123 & 1.67022 & $\begin{array}{l}\text { Hypothesis } \\
\text { received }\end{array}$ \\
\hline
\end{tabular}

The above table explained that the results of $t_{\text {count is }} 6.123$ while for $r_{\text {table }}$ with $n=63$, the value of $\mathrm{df}=\mathrm{n}-2$ with a degree of confidence of $5 \%$ is 1.67022 . It is concluded that $t_{\text {arithmetic }}>$ $\mathrm{t}_{\text {table }}$ so that the hypothesis is accepted, therefore Perception of World of Work Information (X) affects Student Work Readiness (Y).

The results of the calculation of the coefficient of determination will be explained in the following table:

\section{TABLE VI. DETERMINATION TEST}

\begin{tabular}{|l|c|}
\hline \multicolumn{1}{|c|}{ Variable } & $\mathbf{R}^{\mathbf{2}}$ \\
\hline $\begin{array}{l}\text { Perceptions of information about the } \\
\text { world of work on student work } \\
\text { readiness }\end{array}$ & 0.381 \\
\hline
\end{tabular}

$\mathrm{KD}=0.381 \times 100 \%$

$\mathrm{KD}=38.1 \%$

Table above shows the coefficient of determination of 0.381 which means that the contribution the independent variable (perception of information on the world of work) to the dependent variable (student work readiness) amounted to $38.1 \%$. For more details, it will be presented in the following diagram:

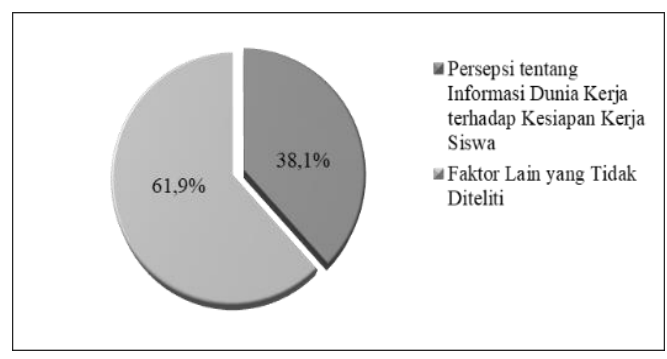

Fig. 5. Determination test.

Based on the diagram above, the coefficient of determination has a percentage of $38.1 \%$. Based on the provisions of $36 \% \leq \mathrm{r}^{2} \leq 64 \%$, which means that the level of influence of variable $\mathrm{X}$ on variable $\mathrm{Y}$ is high. While the percentage of $61.9 \%$ is the influence of other factors that were not examined. The percentage of 38.1 is the effective contribution and 61.9 is the relative contribution. The amount of determination coefficient is in the interval 0 to 1 , which means that the more the coefficient of determination approaches 1, the stronger the influence of the independent variable on the dependent variable.

The conclusion obtained by the perception of information about the world of work that is good will form high student work readiness. Students who enrich themselves with information on the world of work will have a work-ready mentality that forms high job readiness. Examining perceptions of information on the world of work is not enough to determine the extent of student work readiness. Research is needed on other factors that are considered to affect student work readiness such as industrial work practices, motivation to enter the world of work, interests, talents, intelligence abilities, and so on.

\section{CONCLUSION}

Perceptions of information about the world of work are in the very good category. The achievement of perceptions about information on the world of work for each study program is classified as evenly distributed with very good results. Student work readiness is in the very high category. The readiness of work possessed by students for each study program is evenly classified in the very high category. The effect of perceptions of information on the world of work on work readiness of students of Vocational High School 1 Sumedang, the results showed that perceptions of information on the world of work had a high effect on work readiness of students at State Vocational High School 1 Sumedang.

The recommendations from the results of research and discussion of the influence of perceptions about information on the world of work on work readiness of students at State Vocational High School 1 Sumedang, including the following:

- Students are expected to continue to seek and increase information about the world of work. Information does not only come from schools, it can be from print media, internet, social media, from alumni or family, professional seminars, and so on. Perceptions of good information about the world of work are proven to affect job readiness in the category of strong influence.

- For schools, it is hoped that there will be follow-up to students regarding perceptions of information on the world of work that students have, especially for TKJ, TAV, and RPL study programs because the three study programs occupy the lowest position in the perception of information on the world of work. So that all students have access to information on the world of work that is evenly distributed from various sources effectively and efficiently. Expand to build partners with companies in order to increase company links for each department at SMKN 1 Sumedang.

- For further research, research on perceptions of information on the world of work on work readiness is limited to communication access. Further researchers are also advised to increase the number of samples and 
conduct interviews with students or open questionnaires to determine the qualitative responses of students. In addition, researching perceptions about information on the world of work is not enough to know the extent of the influence on work readiness, therefore it is recommended to also examine other factors that affect work readiness such as industrial work practices, motivation to enter the world of work, student intelligence, student competence, interests, talents, and others.

\section{REFERENCES}

[1] P. Anoraga, Psikologi Kerja. Jakarta: Rineka Cipta, 2009

[2] S. Arikunto, Prosedur Penelitian Pendidikan. Jakarta: Rineka Cipta, 2010

[3] A. Fitriyanto, Ketidakpastian Memasuki Dunia Kerja karena Pendidikan. Jakarta: Rineka Cipta, 2006.

[4] O. Hamalik, Proses Belajar Mengajar. Jakarta: Bumi Aksara, 2008.

[5] M. Hasibuan, Organisasi \& Motivasi Dasar Peningkatan Produktivitas. Jakarta: Bumi Aksara, 2007.

[6] H. Hastuti and W. Wingkel, Bimbingan Konseling di Institusi Pendidikan. Yogyakarta: Media Abadi, 2007

[7] R. Jalaludin, Psikologi Komunikasi. Bandung: Remaja Rosdakarya, 2005

[8] J. Jogianto, Analisis Desain dan Sistem Informasi: Pendekatan Terstruktur dan Praktik Aplikasi Bisnis. Yogyakarta: Andi Offset, 2005.

[9] R.F. Johnson and R. Je, Theory and Management Of System. Tokyo: Mc. Graw. Hill, 1973.

[10] K. Kartono, Menyiapkan dan Memandu Karier. Jakarta: CV. Rajawali, 1991.

[11] P. Kotler, K. Keller, S. Ang, C.T. Tan and S.M. Leong, Marketting Management: an Asian Perspective. Pearson, 2018.

[12] P. Prayitno and E. Amti, Dasar - Dasar Bimbingan dan Konseling. Jakarta: Rineka Cipta, 2013

[13] P. Priyono, Metode Penelitian Kuantitatif. Sidoarjo: Zifatama Publishing, 2016.

[14] S. Simanjuntak, Produktivitas Kerja Pengertian dan Ruang Lingkupnya. Jakarta: LP3ES, 1993.

[15] S. Slameto, Belajar dan Faktor - Faktor yang Mempengaruhi. Jakarta: Rineka Cipta, 2010.

[16] S. Sugiyono, Metode Penelitian Pendidikan Pendekatan Kuantitatif, Kualitatif dan R\&D. Bandung: Alfabeta, 2009

[17] S. Sugiyono, Metode Penelitian Pendidikan Pendekatan Kuantitatif, Kualitatif, dan R\&D. Bandung: Alfabeta, 2010

[18] S. Sugiyono, Metode Penelitian Pendidikan Pendekatan Kuantitatif, Kualitatif, dan R\&D. Bandung: Alfabeta, 2012
[19] D.K. Sukardi, Bimbingan Karir di Sekolah - Sekolah. Denpasar: Bumi Aksara, 1993.

[20] D.K. Sukardi, Bimbingan Karir di Sekolah - Sekolah. Denpasar: Bumi Aksara, 1984

[21] D. Susanti, "Pengaruh Informasi Dunia Kerja dan Kreativitas Siswa terhadap Kesiapan Kerja Siswa SMK YPPK 2 Sleman," Jurnal Kajian Pendidikan Akuntansi, pp. 1-27, 2011.

[22] B. Walgito, Bimbingan dan Konseling Perkawinan. Yogyakarta: Andi Offset, 2004

[23] J. Adri, "Pengaruh Pengalaman Praktik Kerja Industri dan Informasi Dunia Kerja Terhadap Minat Berwirausaha," Jurnal Univeristas Negeri Padang, 2013.

[24] M.Z. Alfian and S. Subagyo, "Pengaruh Informasi Dunia Kerja Dan Pengetahuan Tentang Ilmu Keteknikan Terhadap Kesiapan Menjad Guru SMK Mahasiswa Semester 5 Pendidikan Teknik Mesin FKIP UST Tahun Akademik 2015/2016," Taman Vokasi, vol. 5, no. 1, pp. 111-123, 2017.

[25] B. Burgaz, "Employability competences of vocational secondary school students," Egitim Arastirmalari-Eurasian Journal of Educational Research, vol. 31, pp. 17-34, 2008

[26] N. Fitriyaningsih, Pengaruh Persepsi Siswa tentang Kompetens kejuruan Motivasi Memasuki Dunia Kerja dan Informasi Dunia Kerja terhadap Kesiapan Kerja Siswa Kelas XII Program Keahlian Administrasi Perkantoran SMK Negeri 1 Kendal. 2017. PhD Thesis. Universitas Negeri Semarang, 2017.

[27] T. Järvinen, N. Eklöf and L. Salminen, "Factors related to nursing students' readiness to enter working life-A scoping literature review," Nurse education in practice, vol. 29, pp. 191-199, 2018.

[28] N.R. Katarini, Burnout Pada Karyawan Ditinjau Dari Persepsi Budaya Organisasi dan Motivasi Intrinsik di PT. Krakatau Steel, 2011.

[29] Y. Kusnaeni, Pengaruh Persepsi Tentang Praktik Kerja Lapangan, Informasi Dunia Kerja dan Motivasi Memasuki Dunia Kerja Terhadap Kesiapan Kerja Siswa SMK Bhakti Persada Kendal. Diss. UNIVERSITAS NEGERI SEMARANG, 2015.

[30] E. Prabawati, Pengaruh Motivasi Memasuki Dunia Kerja dan Pengalaman Praktik Kerja industri Terhadap Kesiapan Kerja Peserta Didik Kelas XII Program Keahlian Akuntansi SMK Negeri 1 Tempel, pp. 12-30, 2012.

[31] C. Septyanita, "Pengaruh Informasi Dunia Kerja Dan Pengalaman Praktik Kerja Industri Terhadap Kesiapan Mental Menghadapi Dunia Kerja Siswa Kelas Xii Program Keahlian Teknik Kendaraan Ringan Smk Negeri 2 Sukoharjo Tahun Ajaran 2013/2014,” Jurnal Nosel, vol. 3 , no. 2,2014

[32] D. Susanti, "Pengaruh Informasi Dunia Kerja dan Kreativitas Siswa terhadap Kesiapan Kerja Siswa SMK YPKK 2 Sleman,” Jurnal Kajian Pendidikan Akuntansi, pp. 1-27, 2011

[33] Badan Pusat Statistik tentang Tingkat Pengangguran Terbuka Indonesia 2019

[34] Undang-Undang Republik Indonesia Nomor 20 Tahun 2003 Tentang Sistem Pendidikan Nasional. 